\title{
Pre-Service Teachers' Reflective Practice and their Teaching Practicum Beliefs
}

\author{
Arlon P. Cadiz \\ College of Graduate Studies and Teacher Education Research (CGSTER) \\ Philippine Normal University, Manila \\ 104 Taft Ave, Ermita, Manila, 1000 Metro Manila, Philippines \\ E-mail: cadiz.ap@pnu.edu.ph
}

\begin{abstract}
Article Info
Abstract

Received September 2021

Accepted November 2021

Published November 2021

Keywords:

pre-service teachers, reflective practice, teaching practicum

While learning assessment serves as feedback for teachers in maintaining or improving teaching practice, reflective practice play can be seen in how pre-service teachers plan, design, implement and evaluate their teaching approaches. Practicing reflection can help pre-service teachers starting to embrace the value and passion of teaching which manifests in their professional teaching practice. This study was conducted to determine the reflective practice of pre-service teachers and their teaching practicum experience. Involved in this study were 103 pre-service teachers from the government Teacher Education Institution. The study used self-developed survey questionnaires on pre-service reflective practice and beliefs about their teaching practicum. Results showed that there is a significant relationship between the reflective practice of pre-service teachers and their beliefs about teaching practicum. On the other hand, reflective practice as well as the beliefs of male and female pre-service teachers about their teaching practicum does not have a significant difference. Teacher educators should impart reflective practice as part of their teaching practicum. For further research, a wide scope of study may be conducted involving different Teacher Education Institutions in private and public Higher Education Institutions to verify the findings in this study.
\end{abstract}

C2021 Jurusan Ilmu Pendidikan, FKIP Universitas Lampung 


\section{INTRODUCTION}

Teachers are the drivers and the direct implementers of the curriculum in the classroom. They provide direction and guide the students in the way that they should be. Mathew et al. (2017) reiterated that teachers are the greatest assets of any education system. Teachers play a pivotal role in establishing students' interest in learning the subject. They engage students in different learning experiences; deal with the needs and issues of the learners and demand time if they reflect on their daily teaching learning activities, and motivate students to learn is the reflection of the presence of teachers inside a classroom.

Teachers who reflect on their experiences in classroom practice are reflective practitioners. The opportunity to modify their instruction is based on the feedback they've gathered in their classroom. When teachers engage in new strategies, they developed new knowledge and apply it to their instruction integrating various pedagogical approaches. The development of teaching qualities needs reflection in action (during teaching) as well as reflection on action (afterwards) (Park \& Oliver, 2008). Classroom practice is a reflection of teachers' pedagogical content knowledge for teaching wherein teaching practicum can be used as a reflective tool to critically analyze their own experiences and understanding when adopting innovation in teaching practice (Goodnough \& Hung, 2009). Hence, the change in pedagogical practice is a result of reflection (Benade, 2015; Gaciu, Dalzell, Davis, Diamond \& Howard, 2017).

Pre-service teachers are starting to develop their potentials in teaching. Hence, teaching practicum is a good start and first step in applying the principles they've learned from the academe for about 4 years. Moradkhani et al. (2017) argued that teachers should have the opportunity to reflect on their own philosophy of teaching and learning. They can have the ability to plan and organize learning as well as the ability to apply learning strategies (Ma'rufi, Buduyasa \& Juniati, 2017). Hence, through reflective practice, pre-service teachers can study their teaching methods and determine what works best for the students (Larrivee, 2000). Self-assessment will do to reflect on the difficulties and provide necessary interventions. In this manner, reflection using varied techniques could be useful so that pre-service teachers will have the basis 
on how they can improve their teaching. By developing knowledge and understanding the setting practice and the ability to identify and react to the problems the student teachers can become effective teachers (Mathew et al., 2017). These things should start with the training of our pre-service teachers. They need to be honed as early as possible and exposed to the real situation of the educational system in the country particularly in the K12 education arena.

This study explored the reflective practice of pre-service teachers and their beliefs about teaching practicum. Specifically, the study sought answers to the following: (a) determine the reflective practice among pre-service teachers; (b) determine the beliefs of pre-service teachers about teaching practicum; (c) correlate reflective practice of their beliefs about teaching practicum; and (d) determine the difference between male and female pre-service teachers' reflective practice and beliefs about teaching practicum.

\section{Practicing Reflection in Teaching}

Practicing reflection has become a focus of interest and a powerful movement in teacher education and impacts more important in educational outcomes particularly teacher effectiveness and growth in teaching skills (Mathew et al., 2017; Camburn, \& Han, 2017). Many teachers do not reflect as part of their regular routines and they do not have time or opportunity to develop the skill on reflective practice (McNamara, 1990). This practice is one of the attributes of teachers as active members of the professional community (SEI-DOST \& UP NISMED, 2011). Teaching is a complex task requiring a degree of self-reflection and the ability to apply situation-specific solutions in classroom settings (Choy, Yim \& Tan, 2017).

The reflective practice could be described as a way to improve teachers' practice; as an opportunity to renew \& understand the effects of teaching; as the ability to reflect on an action to engage in a process of continuous learning; as a way to enhance the teaching process; and used to help teachers modify and craft their instruction to support students' individual instructional, linguistic, and cultural strengths (Rodriguez, 2008; Jacobs, Vakalisa, \& Gawe, 2011; Mathew et al., 2017; Moradkhani et al., 2017; Vaughn, Parsons, Keyes, Puzio, \& Allen, 2017). 
Reflections can also be used to enhance teachers' development of dispositions, relevant in promoting \& improving instruction in the classroom, improve future decision making in teaching practice, and would benefit students learning (Whitley, 2007; Rayford, 2010; Titilayo \& Uwameiye, 2012; Kelly, 2015). Posthuma (2012) argued that reflecting influences how teachers change their teaching actions. As a result of reflection, the teacher may decide to do something in a different way or to retain his/her teaching practice. Here, there is a need to reflect on the experiences or activities to grow professionally (Mathew et al., 2017). Moreover, reflective practice can help in increasing self-confidence and beliefs of teachers in teaching as they reflect performance in teaching (Appleton, 2008; Freidhoff, 2008; Finlay, 2008; Mathew et al., 2017).

\section{Reflective Practice in Teaching Practicum}

Reflective practice is a helpful tool for pre-service teachers, especially new teachers, towards the professional practice of teachers' subjects (Gaciu et al., 2017; Vaughn et al., 2017). Reflective thinking strategies helped pre-service teachers learn from their experiences. Therefore, it is important that trainee teachers or pre-service teachers are aware of practicing reflection as part of their teaching practicum. Simoncini et al. (Simoncini, Lasen, \& Rocco, 2014) showed that pre-service teacher reflections revealed a deeper understanding of the knowledge and skills-beyond planning and teaching - such as negotiation, problem solving, reflectivity and reflexivity, which are essential in constituting their professional selves.

Hence, practicing reflection in teaching is very useful to pre-service teachers in improving their teaching performance during teaching practicum because they can able to discover their strengths and weakness, hence encouraging better planning in teaching (Rayford, 2010; Aldahmash, Alshmrani \& Almufti, 2017). Reflective practice will help teacher educators determine what experiences and knowledge are included in science education courses and professional development will best facilitate teachers' development of classroom management skills (Deaton, 2013). Korkko et al. (2016) suggested that student teachers' learning has to be supported so that these students reach the stage of critical reflection and it has to be included in the teaching practicum or in some courses in the teacher education program. 
The materials on reflective practice must be included in professional development programs for the pre-service teachers to acquire reflective abilities (more reflective) in their teaching practice (Aldahmash et al., 2017). In developing the reflective practice during the teaching practicum of the preservice teachers, administrators and teacher educators should provide enough opportunities for these trainee teachers to reflect on their own philosophy of teaching and learning (Moradkhani et al., 2017). Changed pedagogical practice is seen as the result of reflection, and rather more as a result of wider changes in the policy and practice environment (Benade, 2015). For this reason, Matthew et al. (2017) argued that student teachers need to grow and bring changes in their behavior and style for their professional development.

\section{METHODS}

\section{Research design}

The descriptive-correlational design directed the analysis to determine the reflective practice and beliefs of pre-service teachers and how their reflective practice correlates to their beliefs about teaching practicum.

\section{Respondents}

A simple random sampling was used to determine the 103 secondary preservice teachers from a public Teacher Education Institution. They were in their teaching practicum from December 2017 - February 2018 deployed to different public junior high schools in Manila and Quezon City divisions. They handled various grade levels and taught Science (29), Mathematics (25), Filipino (21), and TLE (28). There were 39 male and 64 female students. The respondents in this study were fully informed of the purposes and procedures of the study.

\section{Instrument}

Pre-service Teachers' Reflective Practice Survey Questionnaire - A researcher-made survey questionnaire with 26 items and were classified into two constructs: (a) ways of practicing reflection (18 items); and (b) areas of practicing reflection ( 8 items). The survey questionnaire followed the 4-point scale (4-Always; 3 -Sometimes; 2 -Seldom; 1 -Never). 
Survey Questionnaire on Pre-service Teachers'Beliefs about Teaching Practicum - Another researcher-made questionnaire with 21 items to determine the level of beliefs of pre-service teachers about teaching practicum. The survey questionnaire followed the 4-point scale (4 - Strongly Agree; 3 - Agree; 2 Disagree; 1 - Strongly Disagree). The two survey questionnaires were subjected to pilot testing. The Cronbach's Alpha Values of 0.82 and 0.92 were computed for internal consistency respectively.

\section{Data Analysis}

The mean and standard deviation were used to determine the reflective practice and beliefs of pre-service teachers about their teaching practicum. Pearson $r$ was used to determine the relationship between reflective practice and beliefs of pre-service teachers about their teaching practicum experience. Furthermore, a t-Test was used to determine the difference between male and female pre-service teachers' reflective practice and beliefs about their teaching practicum.

\section{RESULTS AND DISCUSSION}

Table 1. Weighted Mean of Reflective Practice of Pre-service Teachers

\begin{tabular}{lccc}
\hline Ways of Practicing Reflection & Mean & SD & Description \\
I am practicing reflection ..... & 2.8447 & .3992 & So \\
\hline through thinking alone. & 3.5437 & .5904 & $\mathrm{~A}^{*}$ \\
expressed in writing alone. & 3.2136 & .4119 & $\mathrm{~A}^{*}$ \\
when I am riding in a public/private transport/vehicle. & 2.9515 & .6914 & So $^{*}$ \\
with my colleagues in the same subject area. & 3.4272 & .4971 & $\mathrm{~A}^{*}$ \\
with my colleagues in other subject areas. & 2.9903 & .6641 & So \\
with my head teacher in the department. & 2.8447 & .6680 & So \\
with the head teacher (s) of the other department(s). & 1.9417 & .9479 & Se \\
with the non-teaching staff such as utility personnel \& & 2.1165 & 1.022 & So \\
$\quad$ security personnel & & & \\
with the canteen staff. & 1.9515 & .9433 & Se \\
by posting something in my social media accounts (e.g. & 2.5243 & .8500 & So \\
$\quad$ FB, Twitter) & & & \\
with my friends in social media (e.g. FB messenger, & 2.9515 & .7718 & So \\
$\quad$ etc.) & & & \\
with my immediate family members. & 3.0583 & .7518 & So \\
with my relatives and extended family members. & 2.6893 & .8635 & So \\
with my close friends. & 3.4660 & .5910 & A* \\
with my neighbors. & 2.2427 & 1.014 & So \\
through playing music. & 3.2913 & .6360 & A* \\
by watching favorite TV shows or movies. & 2.7573 & .9647 & So \\
with my students. & 3.2427 & .8685 & A* \\
\hline Areas of Practicing Reflection & & Mean & Description \\
\hline
\end{tabular}




\begin{tabular}{|c|c|c|c|}
\hline I am practicing reflection & 3.6638 & .3390 & $A^{*}$ \\
\hline when writing a lesson plan. & 3.5243 & .5915 & $\mathrm{~A}^{*}$ \\
\hline when drafting an assessment for my students. & 3.6117 & .4898 & $A^{*}$ \\
\hline when preparing my instructional materials. & 3.6311 & .4849 & $\mathrm{~A}^{*}$ \\
\hline after knowing the test results of my students. & 3.7864 & .4119 & $\mathrm{~A}^{*}$ \\
\hline $\begin{array}{l}\text { when my cooperating teacher is giving suggestions } \\
\text { regarding my } L P \text {, instructional delivery, etc. }\end{array}$ & 3.7379 & .4420 & $\mathrm{~A}^{*}$ \\
\hline $\begin{array}{l}\text { when planning for my upcoming demonstration } \\
\text { teaching. }\end{array}$ & 3.8350 & .3730 & $\mathrm{~A}^{*}$ \\
\hline $\begin{array}{l}\text { when searching for learning resources using different } \\
\text { browsers in internet. }\end{array}$ & 3.7282 & .4471 & $A^{*}$ \\
\hline when recording scores of my students. & 3.4563 & .5005 & $\mathrm{~A}^{*}$ \\
\hline
\end{tabular}

$A^{*}-$ Always; So-Sometimes; Se-Seldom; $N-$ Never

As gleaned from table 1, respondents perceived and labeled their reflective practice as 'Sometimes' for the ways of practicing reflection and "Always" for the areas of practicing reflection. Pre-service teachers always practice reflection when thinking alone, while playing music, \& by expressing it through writing when they are alone. This is similar to the result of the study conducted by Aldahmash, et al. (2017) that teachers practice almost most reflection types when they reflect alone. There are also people around these preservice teachers that could serve as their social avenue as they practice reflection such as their close friends, their colleagues in the same subject area, and most particularly with their students. Pre-service teachers sometimes practice reflection with their families, head teachers, colleagues from other subject areas, non-teaching \& canteen staff, while riding a vehicle, with their neighbors, and/or by watching their favorite TV shows and movies. Furthermore, they sometimes practice reflection using their social media accounts such as when they post something and or when chatting with their friends using these social media sites. These results imply that they practice reflection in different ways. Camburn \& Han (2017) argued that reflective practice varies across different teacher work contexts.

Pre-service teachers always practice reflection in the areas that have something to do with their duties and responsibilities. It could be observed when they plan for their lessons, prepare their instructional materials, and search for learning resources on the internet. When it comes to giving assessments to students, pre-service teachers always reflect first before they draft an assessment, after knowing the results of the assessment, and up to recording students' scores. This implies that they are very much aware of the importance 
of assessment. Furthermore, the suggestions of their critic teachers are also important. They always reflect on it as feedback for their upcoming teaching demonstrations as to how they need to improve their lesson plans, instructional delivery strategy up to the appropriate assessment tool. This shows that they are very much particular with the result of their final demonstration teaching, hence, they willingly listen to their criti teachers and made the right preparations for one of the most important dates of their teaching life.

Table 2. Weighted Mean of Pre-service Teachers' Beliefs about their Teaching Practicum

\begin{tabular}{|c|c|c|c|}
\hline $\begin{array}{l}\text { Beliefs of Pre-service Teachers about their Teaching } \\
\text { Practicum }\end{array}$ & Mean & SD & Description \\
\hline As Pre-service Teacher, I can .... & 3.4669 & .3101 & SA \\
\hline prepare a good and well-planned lesson plan. & 3.4757 & .5019 & $\overline{\mathrm{SA}}$ \\
\hline $\begin{array}{l}\text { easily have access to many learning resources using } \\
\text { different electronic sites. }\end{array}$ & 3.3689 & .4849 & SA \\
\hline encourage students to participate in classroom activities. & 3.5340 & .5013 & SA \\
\hline $\begin{array}{l}\text { apply efficient and various teaching techniques in teaching } \\
\text { the subject. }\end{array}$ & 3.4951 & .5024 & SA \\
\hline $\begin{array}{l}\text { deal with management-related issues (e.g. students' } \\
\text { disruptive behavior). }\end{array}$ & 3.4272 & .4971 & SA \\
\hline $\begin{array}{l}\text { modify and craft instruction to support students' } \\
\text { individual learning needs. }\end{array}$ & 3.2718 & .4471 & SA \\
\hline apply real life situations in my discussions. & 3.6408 & .4821 & SA \\
\hline $\begin{array}{l}\text { interact with my students through asking higher-order } \\
\text { type of questions. }\end{array}$ & 3.3204 & .4689 & SA \\
\hline $\begin{array}{l}\text { prepare appropriate and suitable assessment for my } \\
\text { students. }\end{array}$ & 3.4369 & .4984 & SA \\
\hline $\begin{array}{l}\text { integrate multimedia and educational technology in my } \\
\text { classroom. }\end{array}$ & 3.5340 & .5013 & SA \\
\hline $\begin{array}{l}\text { deal and have good interpersonal relations with my } \\
\text { colleagues and teachers. }\end{array}$ & 3.5825 & .4956 & SA \\
\hline $\begin{array}{l}\text { easily follow to things which my cooperating teacher } \\
\text { requires me to do. }\end{array}$ & 3.5340 & .5013 & SA \\
\hline $\begin{array}{l}\text { integrate activities which promote differentiated } \\
\text { instruction. }\end{array}$ & 3.4272 & .4971 & SA \\
\hline $\begin{array}{l}\text { talk with parents confidently with regards to performance } \\
\text { of students. }\end{array}$ & 3.0777 & .7500 & A \\
\hline give immediate and helpful feedback to my students. & 3.4272 & .4971 & SA \\
\hline $\begin{array}{l}\text { prepare activities to my students following inquiry-based } \\
\text { learning. }\end{array}$ & 3.3204 & .4690 & SA \\
\hline construct rubrics to assess performance of students. & 3.3786 & .5793 & SA \\
\hline come at school early before the start of my classes. & 3.6408 & .4821 & SA \\
\hline present my topic in a well-modulated voice. & 3.6408 & .4821 & SA \\
\hline observe schedule of class hours properly. & 3.6408 & .4821 & SA \\
\hline $\begin{array}{l}\text { manage my classroom as to cleanliness, proper } \\
\text { arrangement of chairs, etc. }\end{array}$ & 3.6311 & .4849 & $\mathrm{SA}$ \\
\hline
\end{tabular}

SA - Strongly Agree; A - Agree; D - Disagree; SD - Strongly Disagree 
As gleaned from table 2, pre-service teachers perceived and labeled their teaching practicum experience as 'Strongly Agree'. They believed that as part of the teaching-learning process, they can prepare a good and well-planned lesson plan, can able to have access to many learning resources using different electronic sites, and can integrate multimedia and educational technology in the classroom. These imply that they are confident and knowledgeable in preparing lessons particularly with the integration of technology and varied learning to promote 21st-century technology skills. Furthermore, in the delivery of instruction, they believed that they can apply efficiently and various teaching techniques in teaching the subject and prepare activities to my students following inquiry-based learning to encourage students to participate in classroom activities by integrating activities that promote differentiated instruction, interact with their students through asking the higher-order type of questions and apply real life situations in the discussions. Moreover, pre-service teachers believed that teaching the lesson with a well-modulated voice is very much helpful. Results also show that they believed to have classroom management skills like dealing with students' disruptive behavior, managing cleanliness of the classroom, arrangement of chairs, etc., and observing the schedule of class hours properly.

Furthermore, they believed that they can do these things if they can come to school early before the start of their classes. In this manner, they are starting to have the good attributes of being professional teachers. Pre-service teachers also ensure the need of having the right assessment and evaluation as evident indicators of students' achievement. They can prepare appropriate assessments for the students by constructing rubrics to assess students' performance. Hence, they can give immediate feedback to the students and can modify and craft instruction to support students' learning needs. Akalin \& Sucuoglu, (2015) found out in their study that performance feedback was found to have positive effects on teacher-use of target classroom management skills. Pre-service teachers also believed in the importance of interpersonal relations with the people around them. When it comes to modification in improving instruction, the changed pedagogical practice is a result of reflection (Benade, 2015; Gaciu et al., 2017).

Pre-service teachers are confident and know how to deal with each other and can easily follow things that require them to do. Mentoring, according to 
Stanulis \& Floden (2009), promotes professional dialogue and reflection for both the mentor and the teacher who is being mentored. Ingleby (2014) also reported that reflective practice becomes a key component of the mentor/mentee relationship. Saravanan \& Wadi, (2014) argued that feedback given by the supervisor reflected the need to develop confidence among teachers towards pedagogic approaches to teaching and learning. Finally, they can talk with parents regarding student's progress or areas that need improvement. The involvement of parents in the school community particularly in students' needs can able to aid teachers' performance and learners' improvement (Boaduo, Milondzo \& Adjei, 2009). Moradkhani et al. (2017) revealed that teachers who are more engaged in reflective practices are more efficacious in encouraging students to participate in classroom activities, applying efficient and various teaching techniques, and dealing with management-related issues (e.g. students' disruptive behavior). Teachers can deal with the needs and issues of the learners and demand of time if they reflect on their daily teaching-learning activities (Mathew et al., 2017).

Table 3. Reflective Practice of Pre-service Teachers correlated to their Beliefs about Teaching Practicum

\begin{tabular}{|c|c|c|c|}
\hline Reflective Practice \& Beliefs about Teaching Practicum & Mean & SD & $\mathbf{R}$ \\
\hline $\begin{array}{c}\text { Reflective Practice of Pre-service Teachers (Ways of } \\
\text { Practicing Reflection) \& Beliefs about their Teaching } \\
\text { Practicum Experience }\end{array}$ & $2.4487^{\text {a }}$ & .3392 & $.247^{*}$ \\
\hline $\begin{array}{c}\text { Reflective Practice of Pre-service Teachers (Areas of } \\
\text { Practicing Reflection) \& Beliefs about their Teaching } \\
\text { Practicum Experience }\end{array}$ & $\begin{array}{l}3.6638^{\mathrm{b}} \\
3.4469^{\mathrm{c}}\end{array}$ & .3390 & $.343^{* *}$ \\
\hline $\begin{array}{l}\text { - Reflective Practice (Ways of Practicing Reflection) }{ }^{c}- \\
\text { racticum Experience } \\
\text { Reflective Practice (Areas of Practicing Reflection) } \\
\text { Correlation is significant at the .05 level (2-tailed); } p<0 \\
\text { Correlation is significant at the .O1level (2-tailed); } p<\end{array}$ & $\overline{l i e f s} a b o$ & $\overline{\text { Teach }}$ & \\
\hline
\end{tabular}

As gleaned from table 3, the reflective practice of pre-service teachers significantly correlates with their beliefs about teaching practicum experience. The result is similar to the study conducted by Korkko, et.al. (2016) that (1) student teachers' perceptions of their own teaching profession expanded, and they began perceiving themselves not only as teachers but also as educators; (2) pre-service teachers' ability to reflect in practicum situations developed; and (3) the role of practicum sessions is connected to reflection and feedback as well as the specific content and aims of each teaching practicum. This implies that preservice teachers' ways of practicing reflection correlate with their beliefs about 
teaching practicum experience. The same result shows that areas wherein preservice teachers are practicing reflection also correlate with their beliefs about teaching practicum experience.

The beliefs of pre-service teachers about their teaching practicum experience have something to do with the manner in which they practice reflection particularly related to their duties and responsibilities as part of the teaching and learning process. Choy et al. (2012) reported that self-belief and teaching awareness of pre-service teachers are related to reflective thinking. In terms of self-belief which is related to reflective thinking, pre-service teachers viewed themselves in relation to their students and their ability to teach. In terms of teaching awareness which has a significant relationship to reflective thinking, pre-service teachers need to have a certain level of awareness in order to assess students' needs. Another finding in the study conducted by Gaciu et al (2017) was that change in beliefs of pre-service teachers, regarding their subject or pedagogical knowledge, was the result of reflections in response to the new curriculum, conditions, and objectives of teaching and learning. They concluded that reflective accounts made by the trainee teachers are helpful tools and important aspects of teachers' subject or pedagogical knowledge.

Table 4. Comparing Male and Female Pre-service Teachers' Reflective Practice and their Beliefs about Teaching Practicum

\begin{tabular}{|c|c|c|c|c|c|}
\hline Indicators & Gender & Mean & SD & $\begin{array}{c}\text { Mean } \\
\text { Difference }\end{array}$ & $\mathrm{t}$-Statistics \\
\hline \multirow{2}{*}{ Ways of Practicing Reflection } & Male & 2.8333 & .3945 & \multirow{2}{*}{.0061} & \multirow{2}{*}{.077} \\
\hline & Female & 2.8273 & .3870 & & \\
\hline \multirow{2}{*}{ Areas of Practicing Reflection } & Male & 3.6731 & .3327 & \multirow{2}{*}{-.0125} & \multirow{2}{*}{-.188} \\
\hline & Female & 3.6855 & .3235 & & \\
\hline \multirow{2}{*}{$\begin{array}{c}\text { Beliefs about Teaching } \\
\text { Practicum }\end{array}$} & Male & 3.4628 & .3132 & \multirow{2}{*}{.0148} & \multirow{2}{*}{.235} \\
\hline & Female & 3.4479 & .3100 & & \\
\hline
\end{tabular}

Generally, male and female pre-service teachers) perceived and labeled their reflective practice as 'Sometimes' in terms of ways of practicing reflection and 'Always' in terms of areas of practicing reflection. On the other hand, preservice teachers have to focus on their teaching practicum as they always reflect on the areas which have something to do with their teaching practicum. There is a slight difference in the mean scores of the two groups but still, results show that there is no significant difference between the two groups. This means that 
regardless of gender, pre-service teachers do practice reflection in the same ways and in the same areas. Aldahmash et al (2017) found out that demographic variables such as gender do not play a role in teachers' reflection. Results also show that there is no significant difference between male and female pre-service teachers' beliefs about their teaching practicum. The two groups of respondents have the same beliefs with regard to their teaching practicum experience. Acikalin (2014) reported that male and female pre-service teachers do not differ in terms of beliefs towards teaching the subject.

\section{CONCLUSION}

The study underscores the findings which serve as supplementary information in the field of pre-service education. In the Philippine context, this study could contribute to pre-service teachers in strengthening their reflective practice to improve their teaching practicum experience as exposed to the new education curriculum in the country. Indicators show that pre-service teachers' practice reflection primarily focuses on their teaching practicum. They also believe that they were able to apply their learned skills from the academic institution to schools where they had their teaching practicum. The teacher education institution which offers courses in teacher education can integrate programs and activities that could establish the value of reflection to preservice teachers. Several strategies for pre-service teachers to practice reflection are reflective journals/diaries, collaborative learning, recording lessons via videotape or audiotape materials, teacher educator's feedback, peer observation, student feedback, and action research, critical incidents, case studies, reflective dialogical exercises (with peers or mentors), role plays and practical exercises (Finlay, 2008; Mathew et al., 2017).

Furthermore, the reflective practice could be integrated as part of the curriculum to further enhance reflective skills among them. Carlson, Newsome, Gardner \& Taylor (2013) reiterated that it is so important that teachers be exposed to highly educative curriculum materials in their preservice development programs. Reflective practice can be included in the teaching practicum or in some courses in the teacher education program (Korkko, 2016; Aldahmash et al., 2017). Pre-service teachers should establish routines in practicing reflection as part of their learning experiences \& be 
included in their portfolio. Future researchers can consider the wide scope of pre-service teachers from other Teaching Education Institutions to verify results and findings in this study. Other variables may also be considered to find out other factors that could influence the reflective practice of pre-service teachers.

\section{REFERENCES}

Acikalin, F.S. (2014). A Study of Pre-Service Teachers' Science Teaching Efficacy Beliefs During The Elementary Science Laboratory Course. Elsevier-Science Direct Procedia - Social and Behavioral Sciences 141, 221 - 226.

Akalin, S., \& Sucuoglu, B. (2015). Effects of Classroom Management Intervention Based on Teacher Training and Performance Feedback on Outcomesof Teacher-Student Dyads in Inclusive Classrooms. Educational Sciences: Theory \& Practice, 15(3), 739-758.

Aldahmash, A. H., Alshmrani, S. M., \& Almufti, A. N. (2017). Secondary School Science Teachers' Views about Their Reflective Practices. Journal of Teacher Education for Sustainability, 19(1), 43-53.

Appleton, K. (2008). Developing Science Pedagogical Content Knowledge through Mentoring Elementary Teachers. Journal of Science Teacher Education(19), 523-545.

Benade, L. (2015). Teachers' Critical Reflective Practice in the Context of Twenty-first Century Learning, Open Review of Educational Research, 2:1, 42-54, DOI:10.1080/23265507.2014.998159

Boaduo, N.-P., Milondzo, K., \& Adjei, A. (2009). Parent-community involvement in school governance and its effects on teacher effectiveness and improvement of learner performance: A study of selected primary and secondary schools in Botswana. Educational Research and Review, 4(3), 96 105.

Camburn, E.M. \& Han, S.W. (2017): Teachers' professional learning experiences and their engagement in reflective practice: a replication study, School Effectiveness and School Improvement, DOI: 10.1080/09243453.2017.1302968

Carlson, J., Newsome, J.-G., Gardner, A., \& Taylor, J. A. (2013). A Framework for Developing Pedagogical Content Knowledge: The Role of Transformative Professional Development and Educative Curriculum Materials. European Science Education Research Association Conference.

Choy, S. C., Yim, J. S. C. \& Tan, P. L. (2017). Reflective thinking among preservice teachers: A Malaysian perspective. Issues in Educational Research, 27(2), 234-251. http://www.iier.org.au/iier27/choy.pdf

Deaton, C. (2013) Teachers' reflections on effectively managing their classroom: a discussion of how two experienced science teachers examined their classroom management practices. Reflective Practice: International and Multidisciplinary Perspectives, 14:2, 240-257, DOI: 10.1080/14623943.2012.749229

Dervent, F. (2015). The effect of reflective thinking on the teaching practices of pre service physical education teachers. Issues in Educational Research, $25(3)$. 
Finlay, L. (2008). Reflecting on Reflective Practice. Practice-based Profesisonal Learning Center (PBPL).

Freidhoff, J. R. (2008). Reflecting on the affordances and constraints of technologies and their impact on pedagogical goals. Journal of Computing in Teacher Education, 24, 117-122. doi:10.1080/10402454.2008.10784597

Gaciu, N., Dalzell, L., Davis, J., Diamond, A., \& Howard, S. (2017). Trainee Teachers' Reflections on Approaches to Enhance their Subject Knowledge in Physics and Mathematics. Teacher Education Advancement Network Journal, 9(1), 36-44.

Goodnough, K. \& Hung, W. (2009) Enhancing pedagogical content knowledge in elementary science, Teaching Education, 20:3, 229-242, DOI:10.1080/10476210802578921

Ingleby, E. (2014). Developing reflective practice or judging teaching performance? The implications for mentor training, Research in PostCompulsory Education, 19:1, 18-32, DOI: 10.1080/13596748.2014.872917

Jacobs, M., Vakalisa, N. C. G. \& Gawe, N. (2011). Teaching-Learning Dynamics. Cape Town: Pearson.

Kelly, J. (2015). COLLABORATION, COLLEGIALITY, AND COLLECTIVE REFLECTION: A CASE STUDY OF PROFESSIONAL DEVELOPMENT FOR TEACHERS. Canadian Journal of Educational Administration and Policy (JEAP)(69).

Korkko, M., Ammala, O. K., \& Turunen, T. (2016). Professional development through reflection in teacher education. Elsevier - Teaching and Teacher Education, 55, 198-206.

Larrivee, B. (2000). "Transforming teaching practice: becoming the critically reflective teacher"(PDF). Reflective Practice: International and Multidisciplinary Perspectives. 1 (3): 293-307. doi:10.1080/713693162.

Ma'rufi, I., Buduyasa, K., \& Juniati, D. (2017). Pedagogical content knowledge: Knowledge of pedagogy novice teachers in mathematics learning on limit algebraic function. The 1st International Conference on Mathematics, Science, and Computer Science (ICMSC). American Institute of Physics.

Mathew, P., Mathew, P., \& Peechattu, P. J. (2017). REFLECTIVE PRACTICES: A MEANS TO TEACHER DEVELOPMENT. Asia Pacific Journal of Contemporary Education and Communication Technology (APJCECT), 3(1), 126-131.

McNamara, D. (1990). Research on teachers' thinking: its contribution to educating student teachers to think critically. Journal of Education for Teaching, 16(2), 147-160.

Moradkhani, S., Raygan, A., \& Moein, M. S. (2017). Iranian EFL teachers' reflective practices and self-efficacy: Exploring possible relationships. Elservier - System, 5, 1-14.

Park, S. \& Oliver, J. S. (2008). Revisiting the Conceptualisation of Pedagogical Content Knowledge (PCK): PCK as a Conceptual Tool to Understand Teachers as Professionals. Research in Science Education, 38(3), 261-284.

Posthuma, A.B. (2012). Mathematics teachers' reflective practice within the context of adapted lesson study. Pythagoras, 33(3), Art. \#140, 9 pages.http://dx.doi.org/10.4102/pythagoras.v33i3.140

Rayford, C.R. (2010). Reflective practice: The teacher in the mirror. UNLV Theses, Dissertations, Professional Papers, and Capstones. 5. Retrieved from http://digitalscholarship.unlv.edu/thesesdissertations/5 
Rodriguez, S. J. (2008). Teachers' Attitudes towards Reflective Teaching: Evidences in a Professional Development Program (PDP). PROFILE, 10, 91111.

Saravanan, V., \& Wadi , H. (2014). Educational research: A study on teachers' professional practice. 5th World Conference on Educational Sciences WCES. 116 , pp. 3843 - 3847. Elsevier \& Procedia - Social and Behavioral Sciences.

SEI-DOST \& UP NISMED, (2011). Framework for Philippine Science Teacher Education. Manila: SEI-DOST \& UP NISMED.

Simoncini, K. M., Lasen, M., \& Rocco, S. (2014). Professional Dialogue, Reflective Practice and Teacher Research: Engaging Early Childhood PreService Teachers in Collegial Dialogue about Curriculum Innovation. Australian Journal of Teacher Education, 39 (1). http://dx.doi.org/10.14221/ajte.2014v39n1.3

Stanulis, N., \& Floden, R. (2009). Intensive mentoring as a way to help beginning teachers develop balanced instruction, Journal of Teacher Education, 60, 112 - 123

Titilayo, O. M., \& Uwameiye, R. (2012). Reflective practice: A strategy for improving teaching practice in Nigerian Colleges of Education. International Journal of Academic Research in Progressive Education and Development, 1(4), $282-294$.

Vaughn, M., Parsons, SA., Keyes, C., Puzio, K., \& Allen, M. (2017) A multiple case study of teachers' visions and reflective practice, Reflective Practice, 18:4, 526-539, DOI: 10.1080/14623943.2017.1323731

Whitley, C. (2007). Teacher dispositions Retrieved from http://www.napomle.org/keepingMiddleSchoolsSuccessful/Teaching\%20Dispo sitions\%20Chapter\%20NMSA.pdf 